\title{
Budaya Panengen sebagai Representasi Simbolik Kepemimpinan Desa Cikalong
}

\author{
Engkus \\ Universitas Islam Negeri (UIN) Sunan Gunung Djati (SGD) Bandung \\ Jalan A.H. Nasution No. 105 Bandung 40614
}

\begin{abstract}
The main problem in the research is dualism of leadership in the life of the Cikalong village: formal and informal leader. The aim of the research is to collect data, fact and to analyze some problems, either directly or indirectly, to know about the dualism deeply. This research uses a qualitative methodology, and technical approach of the research are observation, interview, and documental histo$r y$. The results of research are some positive and negative influences from gotong-royong system and also from leadership in the life of Cikalong village society. The negative influence is mainly related with Islamic greatness, because of fervently doctrine of forefathers were called cultural of panengen. In other words, the followers have special ritual in certain days that implemented in daily life. The policy of the head of the village as a physical and social development administrator has big enough potential toward implementation of continued national development.
\end{abstract}

Keywords: culture of panengen, value,manners, government of the village

\begin{abstract}
ABSTRAK
Masalah utama dalam penelitian ini adalah adanya dualisme kepemimpinan dalam kehidupan masyarakat di Desa Cikalong: Pemimpin formal dan pimpinan informal. Tujuan penelitian ini mengumpulkan data, fakta, dan menganalisis beberapa masalah, baik secara langsung maupun tidak langsung untuk mengetahui dengan mendalam tentang dualisme tersebut. Pendekatan metodologi kualitatif dan teknik penelitian adalah observasi, interview, dan historik dokumental. Hasil penelitian ditemukan adanya pengaruh positif dan negatifnya dari sistem gotong royong serta dari kepemimpinan dalam kehidupan masyarakat di Desa. Pengaruh negatif terutama berkaitan dengan syi'ar Islam yang terhambat, disebabkan oleh karena patuhnya sebagian besar masyarakat menganut ajaran dari leluhurnya yang disebut budaya panengen. Dengan kata lain para penganutnya masih melaksanakan ritual khusus di waktu-waktu tertentu yang terimplementasi dalam kehidupan sehari-hari. Kebijakan kepala desa sebagai administrator pembangunan fisik dan kemasyarakatan berpotensi besar terhadap keberlanjutan pembangunan nasional.
\end{abstract}

Kata kunci: budaya panengen, tata nilai, budi pekerti, pemerintahan desa 


\section{PENDAHULUAN}

Budaya panengen adalah sub sistem, bagian atau jenis dari religi yang merupakan unsur dari kebudayaan, sebagaimana dikatakan B. Malinowski dalam M. Munandar Sulaeman (2012:38), kebudayaan di dunia mempunyai tujuh unsur universal, yaitu: (1) bahasa, (2) sistem, teknologi, (3) sistem mata pencaharian, (4) organisasi sosial, (5) sistem pengetahuan, (6) religi, (7) kesenian, sehingga religi merupakan bagian dari budaya. Fenomena Budaya panengen di Desa Cikalong Kecamatan Sidamulih kabupaten Pangandaran, bagi penulis menarik untuk dibahas, paling tidak dari dua sisi: pertama dari sisi budaya, dan kedua dari sisi studi administrasi publik, di mana Kabupaten Pangandaran merupakan Daerah Otonom Baru (DOB) yang berbasis wisata. Hal utama yang menarik dalam penelitian ini adalah ketaatan penganut budaya panengen. Ketaatan terhadap para pimpinan informal (sesepuh/guru) dan ketaatan kepada kepala desa (pemimpin formal), tersirat makna mempunyai fungsi sosial (tata nilai) tertentu dalam kaitannya dengan pelaksanaan pembangunan. Dengan demikian, penulis memahaminya bahwa di masyarakat desa Cikalong terdapat dualisme kepemimpinan yakni pertama, di antara para penganut budaya panengen yang berpangkal dari pimpinan informal (sesepuh), dan kedua para agent of development yang berpangkal dari pemimpin formal (kepala desa). Dualisme adalah konsep yang menyatakan ada dua substansi.

"Dualism. Duality; use of dual number; theory recognizing two independent principles (mind $\mathcal{E}$ matter, cf,. Idealism $\mathcal{E}$ materialism; good $\mathcal{E}$ evil in the universe; two personalities in Christ)" (H.W.Fowler and F.G Fowler, 1952:370).

Sedangkan kepemimpinan (leadership) merupakan proses pengaruh memengaruhi antar pribadi atau antar orang dalam suatu situasi tertentu, melalui proses komunikasi yang terarah untuk mencapai tujuan/tujuan-tujuan tertentu. Di dalam kepemimpinan selalu terdapat unsur pemimpin (influencer) yakni memengaruhi tingkah laku pengikutnya (influencee) atau para pengikut-pengikutnya dalam suatu situasi (The Liang Gie, dkk., 1982:182).

Studi budaya panengen dalam kontek kepemimpian (leadership) terdapat dua fokus:

1. Bagaimana penganut budaya panengen tumbuh sebagai tata nilai di Desa Cikalong;

2. Bagaimana peran sesepuh/guru sebagai representasi simbolik pimpinan informal (informal leader) di desa Cikalong.

Dalam konteks kajian teoretik untuk memahami tentang religi masyarakat yang di dalamnya ada panengen, maka terlebih dahulu dipahami arti religi dan arti masyarakat. Pengertian religi menurut Moh. Syafa'at (1961):

1. Dalam bahasa Romawi kuno Cicero berasal dari kata latin yaitu religere berarti melakukan sesuatu perbuatan dengan penuh penderitaan atau mati-matian; perbuatan yang dimaksud di sini adalah berupa usaha-usaha atau sejenis peribadatan yang dilakukan berulang-ulang. Jadi, religi cuma upacara agama atau riten.

2. Lactanius. Religi dari kata religare yang berarti mengikat menjadi satu atau menitikberatkan pada kependetaan sesuai dengan ajaran jema'ah Kristen.

Dari kedua pengertian tersebut dapat ditarik suatu kesimpulan bahwa religi adalah suatu pengalaman batin dari kehidupan bersama tentang kejiwaan manusia yang kemudian menimbulkan perilaku manusia tertentu yang dipersembahkan kepada suatu kewajiban atau zat tertentu yang menguasai manusia dan alam seluruhnya.

Selanjutnya arti masyarakat dikemukakan oleh Ralph Linton dan M.J. Herkovits yang menyatakan sebagai berikut: Ralp Linton (dalam Harsojo, 1977:144), menya- 
takan, "Bahwa masyarakat dikemukakan sebagai setiap kelompok manusia yang telah cukup lama hidup dan bekerja sama sehingga mereka itu dapat mengorganisasikan dirinya dan berfikir tentang dirinya sebagai satu kesatuan sosial dengan batas-batas tertentu". Selanjutnya dijelaskan oleh M.J. Herkovitas dalam Harsojo (1977), yang menulis bahwa masyarakat adalah kelompok individu yang diorganisir yang mengikuti satu cara hidup tertentu. Dari kedua pengertian tersebut dapat disimpulkan bahwa masyarakat merupakan sehimpunan orang yang hidup bersama dalam suatu tempat dengan ikatan-ikatan aturan yang tertentu.

Oleh karena itu, dapat dikatakan bahwa religi masyarakat bertalian dengan:

1. The system of beliefs (sistem kepercayaan).

2. Faham, ajaran nenek moyang yang berfungsi mengatur hubungan individu atau kelompok individu satu sama lainnya.

\section{METODE}

Peneltian ini menggunakan pendekatan metodologi penelitian kualitatif yang bersifat inferential, yaitu metode penelitian untuk masalah-masalah yang aktual yang sedang terjadi dalam kehidupan masyarakat (Masri Singarimbun, 1994:5).

Adapun teknik pengumpulan data yang dipergunakan adalah sebagai berikut:

1. Teknik observasi yaitu pengamatan secara langsung terhadap objek-objek yang perlu diteliti serta berhubungan dengan masalah yang akan dibahas;

2. Teknik wawancara atau tanya-jawab yaitu mengadakan pembicaraan dengan aparatur desa dan tokoh masyarakat yang ada kaitannya dengan objek dan masalah yang diteliti;

3. Historik dokumental, teknik ini dipergunakan untuk memperoleh bahanbahan yang berhubungan dengan teori- teori yang dapat dipakai sebagai bahan dasar untuk membahas, memahami dan menjelaskan masalah dan objek yang sedang diteliti. Teknik ini dipergunakan juga untuk bahan perbandingan (Tutik Rachmawati, 2016:13).

Dengan melihat dokumen yang tersedia di Desa Cikalong peneliti bermaksud untuk melihat realisasi pembangunan nasio-nal sebagaimana digariskan dalam Rencana Pembangunan Nasional untuk di tingkat desa, juga untuk melihat data historis Desa Cikalong.

\section{HASIL DAN PEMBAHASAN}

Objek studi atau yang menjadi lokus adalah Desa Cikalong Kecamatan Sidamulih kabupaten Pangandaran. Berdasarkan Laporan Kepala Desa Cikalong (2015), dari data historik dan hasil wawancara dengan para tokoh masyarakat bahwa sampai dengan tahun 1867 belum ada pemerintahan yang resmi.

Dilihat secara geografis pada saat ini, Desa Cikalong pada mulanya berdiri di daerah Kalitalang. Yang menjadi penguasa pada waktu itu adalah Prajawijaya. Kemudian diganti oleh anaknya yang bernama Muni. Pada waktu itu pemerintahan dia ibukota Desa Cikalong dipindahkan ke daerah Dukuh (bagian dari kampung Cikalong sekarang). Beberapa tahun kemudian dipindahkan ke Tundagan kampung Ciheras, dan akhirnya dipindahkan ke kampung Cipari hingga tahun 1979.

Menurut Upang Supandi (2014), Kuwu (Kepala Desa) yang memegang pemerintahan dari tahun 1867 sampai sekarang adalah:

(1) Prajawijaya memerintah sampai tahun 1867; (2) Nakem (1867-1872); (3) Alireja (1872-1878); (4). Dogleg (1878-1885); (5) Suradisastra (1885-1901); (6) Tanuwijaya (1901-1937); (7) Ating (PJ) (1937-1938); (8) Wangsadimaja (1938-1946); (9) Nataatmaja (1946-1950); (10) Kisnapraja (PJ) (1946- 
1950); (11) Wangsadimaja (PJ) (1946-1950);

(12) Kardaya Hadiwarsito (1950-1962); (13) Kisnapraja (PJ), (1962-1963); (14) Mu'min Winitaharja (1963-1979); (15) Mu'min Winitaharja (PJ), (1979-1980); (16) Karnaen (19801988); (17) Koceng Suherman (1988-1996); (18) Siplin Sutisna (1996-2006); (19) Maman S. (2006-2013); dan (20) Upang Supandi (2013-Sekarang).

Desa Cikalong batas wilayahnya dibatasi oleh beberapa wilayah administratif di antaranya: Sebelah utara, berbatasan dengan Desa Kersaratu; sebelah selatan: Berbatasan dengan Desa Sukaresik; sebelah timur: Berbatasan dengan Desa Sidamulih; sebelah Barat: Berbatasan dengan Desa Bojong dan Salasari. Sedangkan iklim di Desa Cikalong sangat dipengaruhi oleh spesifikasi daerah pesisir dengan ketinggian 11 meter di atas permukaan air laut, serta suhu rata-rata menunjukan $27^{\circ} \mathrm{C}$ sampai $36^{\circ} \mathrm{C}$.

Dengan demikian, sangat mungkin untuk permukiman dan bertani serta beternak. Hal ini terbukti dengan berkembangnya kelompok peternakan, serta tanaman khas kelapa, padi yang dipadukan dengan tanaman lainnya seperti cengkeh, serta palawija lainnya yang bermanfaat.

Menurut Upang Supandi (2014), jumlah penduduk sebanyak 3.318 jiwa terdiri dari: laki-laki (1.614 jiwa), perempuan (1.704 jiwa). Jumlah Kepala Keluarga $=1.273$ orang. Kepadatan penduduk rata-rata 3 orang perkilometernya. Selanjutnya, kondisi seni budaya: Seni Ibing Sunda/Ronggeng Gunung $=2$ grup, Qosidahan $=3$ Grup, Orkes Melayu $=1$ Grup, Kuda Lumping/Ebeg $=1$ Grup, Tembang Beluk/Eok= 2 Grup, Tembang Pupuh Wawacan buhun = 6 Grup.

Sedangkan yang menjadi fokus studi ini adalah Budaya panengen yang merupakan ageman (anutan, ajaran/tata nilai yang turun-temurun) pada masyarakat Desa Cikalong Kecamatan Sidamulih Kabupaten Pangandaran, yang dalam ajarannya terdapat nilai kearifan yang luhur. Hakekat hidup dan mati yang mempunyai fungsi tertentu dalam mengatur kehidupan bermasyarakat, bahkan merupakan kelakuan keagamaan (religious behaviour) (Koentjaraningrat, 1983). Kehidupan yang dicerminkan oleh perilaku ketaatan, keteraturan, toleran, persaudaraan, dan gotong royong yang merupakan warisan sosial nenek moyangnya yang masih terus terpelihara sehingga nampak sistem kekerabatan yang sangat erat. Di Desa Cikalong khususnya di Dusun Citembong (di sebagian Dusun Cikalong, dan sebagian kecil Dusun Cimanggu), masih ada tetekon (ajaran/anutan, ageman) yang nampaknya masih kokoh dipegang (dianut) ajaran/ritual oleh para penganut sistem religi tersebut, serta ajaran ini mempunyai manifestasi yang unik dibandingkan dengan masyarakat pada umumnya.

Tradisi rutin budaya panengen ini dilaksanakan secara turun temurun hingga saat ini, yang pelaksanaannya pada waktu tertentu, bulanan, bahkan ada yang dilaksanakan ritual rutin tahunan. Istilah panengen berasal dari bahasa Sunda artinya tengen (katuhu = kanan), kanan identik dengan baik/kebaikan, mengandung silokal simbol bahwa manusia harus menjalani kehidupan dengan berbuat kebaikan (berperilaku baik). Contoh jangan mencuri, jangan mengambil barang milik orang lain, falsafah kehidupan mereka adalah "mipit kudu amit ngala kudu menta" (mengambil barang orang lain harus sepengetahuan pemiliknya). Secara filosofis hal itu bermakna bahwa suatu barang ada pemiliknya termasuk badan kita sendiri ada yang memilikinya, ada yang membimbingnya, ada yang ngasuh (istilah di kalangan para penganut budaya panengen). Hal-hal demikian terus dianut dan berakar jadi nilai sosial dalam kehidupan hingga saat ini.

Berdasarkan hasil wawancara dengan beberapa tokoh dan sesepuh bahwa asalusul budaya panengen berasal dari kampung Cipepetek desa Kondangjajar keca- 
matan Cijulang kabupaten Pangandaran. Para karuhun desa Cikalong menimba ilmu dari daerah tersebut, kemudian berkembang dan turun-temurun di desa Cikalong dan sekitarnya.

Regenerasi dalam penurunan budaya ini sangat rapi dan rahasia. Kehidupan sederhana (basajan) merupakan bagian dari interaksi setiap hari, namun secara tata nilai luar biasa (aheng) dapat mengatur interaksi, cerminan komitmen, integritas serta loyalitas/solidaritas antar sesama.

Dari hasil pengamatan penulis bahwa implementasi budaya panengen dalam ritual terdapat paling tidak ada 11 (sebelas) jenis ritual, sebagai ritual panengen yakni, babarit, ngadegkeun, kaliwonan, nyanggar, nganyaran, ngamulud, ngabuku taun, sidekah/sasajen, nyapu, nambaan, dan mamahanan.

1) Babarit

Ritual babarit biasanya dilaksanakan pada saat akibat ada gempa (lini orang Sunda).

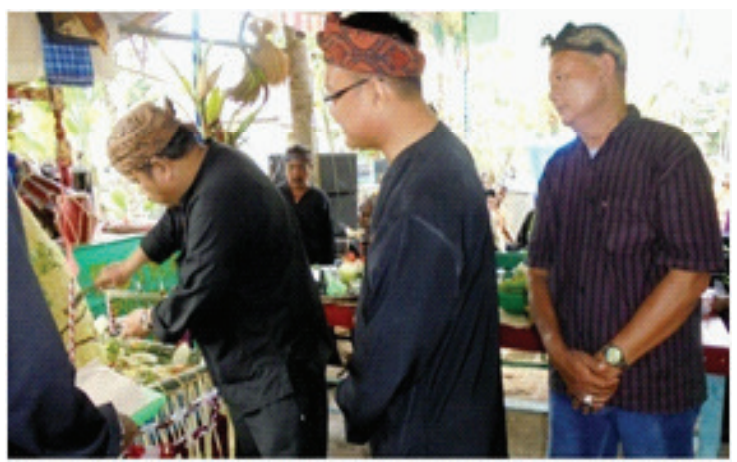

Gambar 1. Babarit

Sumber: Aman Suherman, 2015

\section{2) Ngadegkeun}

Kegiatan ini dilaksanakan pada setiap akan mendirikan bangunan, $n g a d e g=$ berdiri.

\section{3) Kaliwonan}

Momen hari-hari kaliwon ini, sering dimanfaatkan para penganut untuk memandikan bayi umur di bawah lima tahun (BALITA). Paling istimewa adalah ketika malam Jum'at Keliwon.

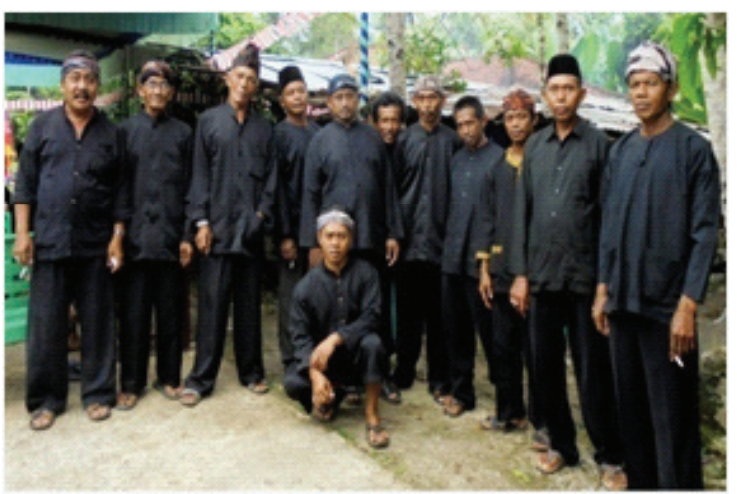

Gambar 2. Ngadegkeun

Sumber: Aman Suherman, 2015

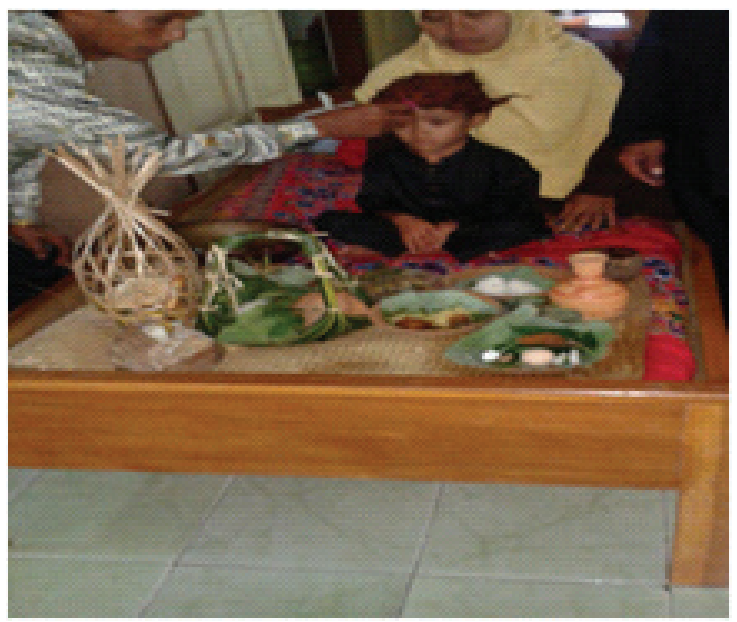

Gambar 3. Kaliwonan

Sumber: Usman, 2016

4) Nyanggar

Ritual musiman ini dilaksanakan ketika akan panen dengan menyuguhkan sesaji yang disimpan di sawah yang akan dipanen.

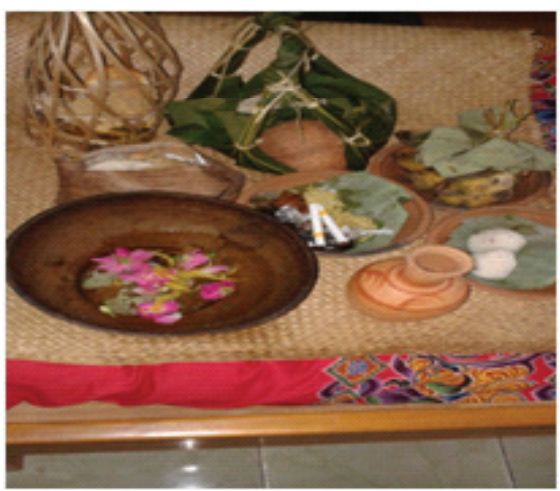

Gambar 4. Nyanggar

Sumber: Usman, 2016

5) Nganyaran

Ritual kegiatan ini dilaksanakan pasca 
panen. Nganyaran artinya anyar = baru, berarti petani mulai merasakan padi/ beras yang baru.

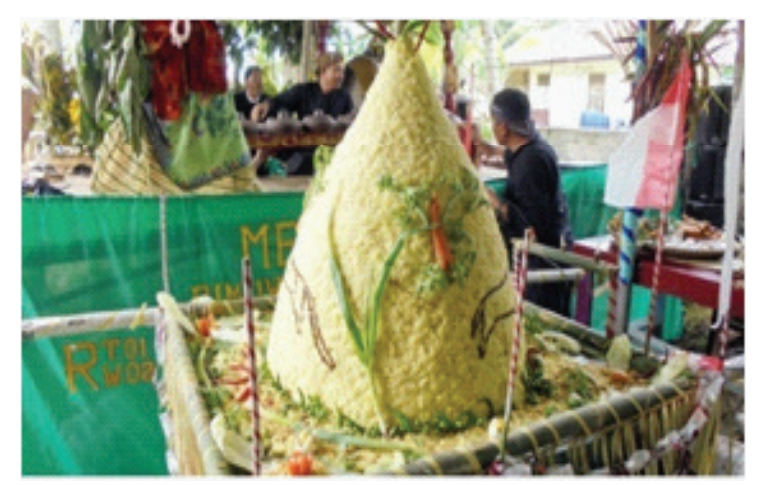

Gambar 5. Nganyaran

Sumber: Aman Suherman, 2015

6) Ngamulud

Setiap Bulan Robi'ul Awwal (Mulud) ada ritual penganut sistem religi yang dipimpin oleh sesepuh, bahkan berdasarkan hasil wawancara dengan beberapa tokoh masyarakat bahwa tradisi tiap tahun pada setiap bulan ini dilaksanakan pematangan ilmu-ilmu mereka, yang disebut Elmu Panengen.

Ritual ini dilalui melalui persiapan-persiapan khusus, baik jiwa dan raga (fisik), secara kejiwaan para penganut harus hafal beserta maknanya atas beberapa mantra sesuai tingkatannya, karena akan diuji oleh sesepuh. Secara fisik harus dipersiapkan sejak siang menjelang sore dengan beberesih diri (mandi besar). Pada akhir puncak ilmu ini, dimaknai "Paeh Sajeroning Hirup, jeung Hirup ku Huripna".

Momen ngamulud ini juga dimanfaatkan oleh para penganut untuk memandikan perkakas buhun seperti: keris, golok, batu ali, alat-alat kesenian buhun dan lainlain perkakas sejenisnya yang diwariskan leluhur secara turun temurun.

\section{7) Ngabuku taun (Muharaman)}

Pelaksanaan ritual ngabuku taun (muharaman) ini biasanya lebih ramai dan masyarakat umum dapat mengikuti prosesi ini, dari mulai ritual oleh sesepuh sampai

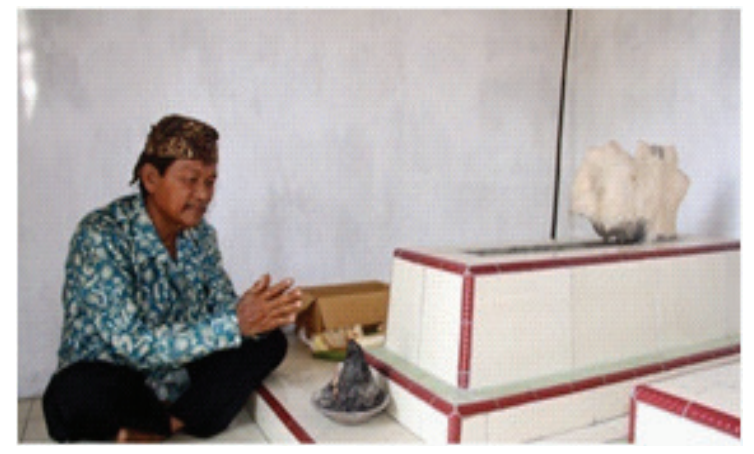

Gambar 6. Ngamulud Sumber: Aman Suherman, 2015

dengan puncak acaranya di malam hari, dengan pentas kesenian wayang golek, wayang kulit atau seni buhun tradisional seperti ronggeng gunung, ronggeng amen dan atau tembang buhun wawacan.

Ritual ini dilaksanakan pada setiap bulan Muharram, yang waktu serta tempatnya sangat ditentukan oleh sesepuh.

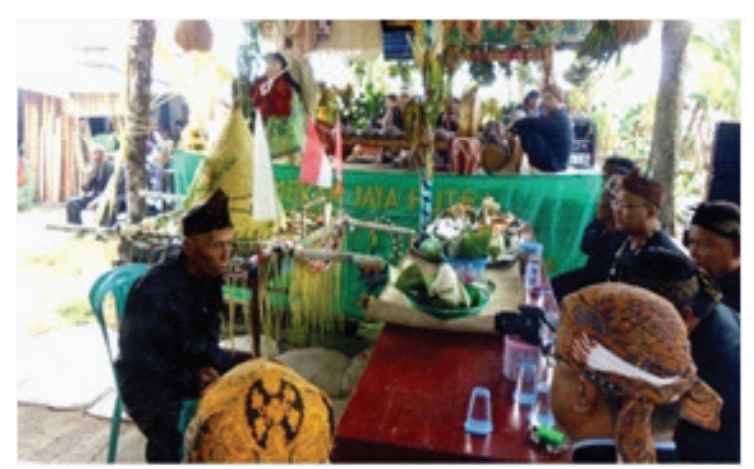

Gambar 7. Ngabuku taun

Sumber: Aman Suherman, 2015

\section{8) Sasajen (Sidekah)}

Ritual ini adalah untuk memperingati orang yang sudah meninggal dunia yang disebut dengan ritual sasajen (untuk Dusun Cikalong dan Citembong), atau sidekah (Dusun Cimanggu).

\section{9) Nyapu}

Pelaksanaan ritual ini biasanya dilaksanakan di makam/kuburan leluhur, karuhun/sesepuh, orang tua, kerabat saudara yang meninggal, yang ritualnya dilaksanakan setelah hari raya Iedul Fitri, tetapi khusus untuk hari Sabtu merupakan larangan melaksanakan ritual ini. 


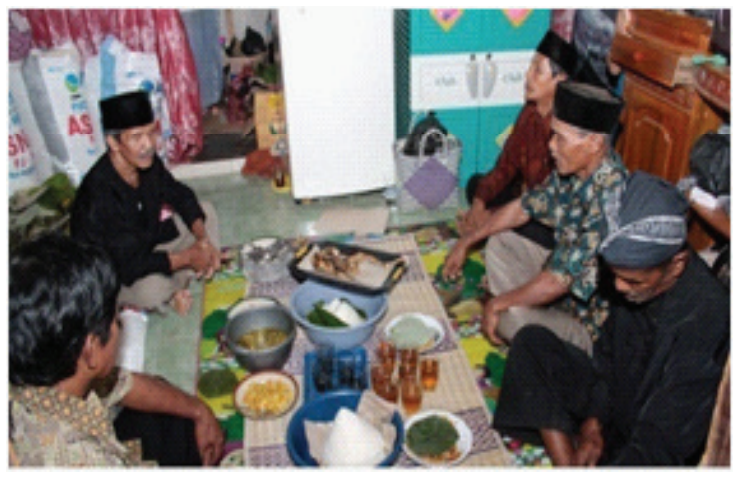

Gambar 8. Sasajen (Sidekah) Sumber: Usman, 2016

Ritual nyapu ini selain dilaksanakan juga ketika akan ada hajatan sepitan, atau hajatan lainnya.

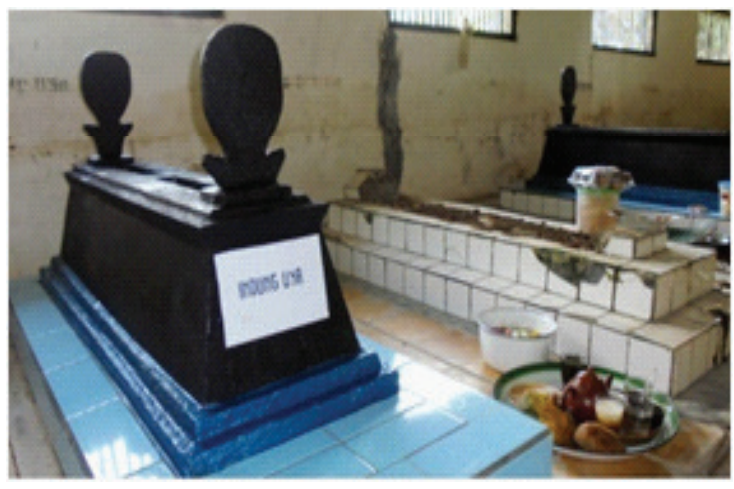

Gambar 9. Nyapu

Sumber: Aman Suherman, 2015

10). Nambaan

Nambaan (pengobatan) merupakan ritual khusus yang dilakukan oleh sesepuh (guru), atau murid yang telah hatam (tamat) belajar ilmu panengen dan diizinkan oleh guru/sesepuh. Ritual ini dilaksanakan ketika ada warga masyarakat meminta disembuhkan dari penyakit yang diderita, tanpa permintaan dari warga masyarakat tidak pernah dilakukan ritual nambaan. Ritual ini biasanya dilakukan dengan melalui media teko merah (tembaga), air putih, daun-daunan (herbalis) dan sejenisnya yang diberikan mantra-mantra sebelumnya oleh sesepuh.

Teko merah (tembaga), melambangkan kekuatan, air merupakan penghantar dari makhluk/pemohon/sesepuh dengan jampi-jampinya sesepuh kepada yang ngasuh diri manusia (Sang Pencipta/Kholik).

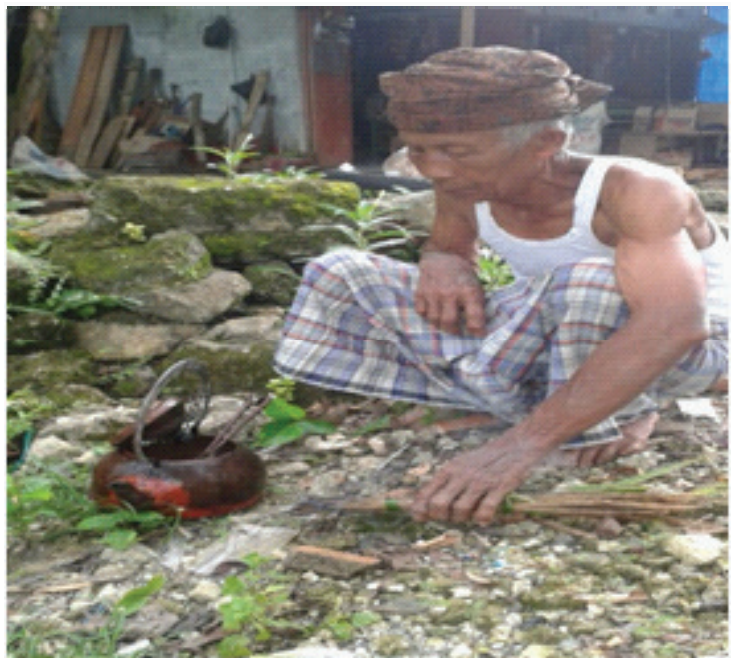

Gambar 10. Nambaan

Sumber: Usman, 2016

\section{1). Mamahanan}

Mamahanan (memberi bahan), jalan, petunjuk ke alam akherat kepada sang Kholik (nungasuh). Ritual mamahan ini dilaksanakan oleh guru/sesepuh atau murid yang diizinkan untuk mengurus orang meninggal dan memberikan air yang telah dimantari di dalam pinggan putih (sejenis mangkuk), mangkuk putih melambangkan kebersihan "asal bersih kembali bersih/suci di hadapan Kholik", yang kemudian air tersebut diteteskan ke 9 (sembilan) lubang yang ada dalam tubuh manusia: dua lubang telinga, dua lubang mata, dua lubang hidung, lubang udel, lubang kemaluan, dan lubang dubur. Makna filosofis dari ritual ini bahwa antara dunia dan akherat terhalang dan terbuka oleh sembilan lubang yang ada dalam diri setiap manusia, ini semua harus dibersihkan dari hawa nafsu hewani duniawi, kotorankotoran dosa sepanjang kehidupan di alam dunia, sehingga menghadap Kholik dengan penuh kesucian. Ketika orang meninggal harus diberi pituduh (petunjuk) melalui air yang diteteskan ke sembilan lubang dimaksud untuk menghadap nu ngasuh (membimbing, mengawal) setiap manusia untuk menghadap-Nya dengan pasrah sumerah, teu ngaboga-boga (Pasrah, menyerah bahwa manusia tidak memiliki apa-apa semuanya kepunyaan Allah SWT). 


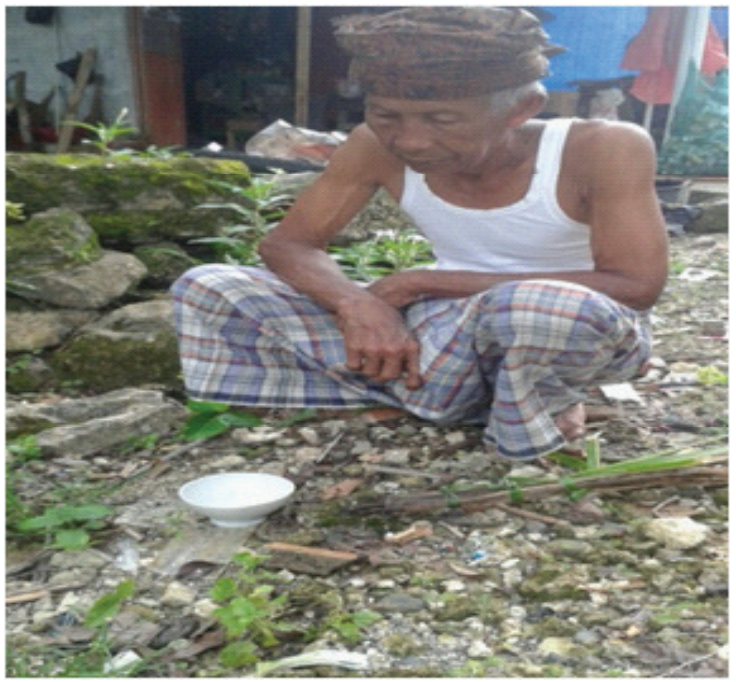

Gambar 11. Mamahanan

Sumber: Usman, 2016

Jenis sesajian untuk setiap ritual biasanya terdiri dari (1) kopi pahit; (2) Sejenis ketupat (istilah mereka tangtang angin dan congcot); (3) telur rebus; (4). rokok, cerutu; (5) kemenyan; (6). bubur sumsum dan; (7) sejenis rerujakan. Ketujuh jenis sesajian ini di kalangan mereka sudah biasa menyebutnya sasajen tujuh rupa.

Dengan demikian, dari tradisi ritual tersebut bahwa peran sentral sesepuh sangat signifikan dan menjadikan ikatan persaudaraan dan ketaatan antar mereka sangat erat, terutama terhadap sesepuh, namun demikian tidak menimbulkan stratifikasi sosial yang tajam antara yang satu dengan penganut yang lainnya, bahkan bilamana dikelola dengan baik oleh pemerintah akan menjadikan energi pendorong (supporting) bagi pembangunan.

\section{Budaya Panengen dan Simbolik Kepe- mimpinan}

Hasil pengamatan penulis, budaya $p a-$ nengen merupakan representasi simbolik kepemimpinan di desa Cikalong ( informal leader). Secara struktural sosial dalam budaya panengen terdapat hubungan emosional dan istimewa antara guru dan murid. Seorang guru (sesepuh) kedudukannya terhormat di kalangan para penganut, segala petuah, pepatah, ajaran yang disampaikan akan menjadi pegangan dalam kehidupan.

Berdasarkan keterangan hasil observasi di masyarakat desa Cikalong dan hasil wawancara dengan sesepuh bahwa seseorang dapat menjadi murid/pengikut setelah memenuhi persyaratan sebagai berikut:

1. Sebelum menjadi murid wajib izin dan memohon do'a kepada kedua orang tua, pengganti orangtua atau suami/istri.

2. Usia minimal 50 tahun (dipandang telah arif/ memadai oleh sesepuh/guru).

3. Murid perempuan berguru ke guru perempuan, laki-laki berguru ke guru lakilaki.

4. Terjaga/suci dari prilaku tercela, dan prilaku negatif lainnya.

5. Menghormati sesepuh (guru), sesama manusia dan makhluk lainnya.

6. Menjaga/melestarikan lingkungan/ alam (tatanen).

7. Jaga bicara (ulah saciduh ciduhna).

8. Menghindari makan yang banyak, dan tidak bertengkar.

9. Tidak berbuat maksiat, mencuri, berbohong, serakah dan tidak menguasai hak orang lain.

10. Melaksanakan pituah guru.

11. Memelihara (ngamumule) elmu panengen.

Penerimaan seseorang menjadi murid sangat subjektif artinya sangat tergantung kepada guru, namun demikian persyaratan inti tetap harus dipenuhi.

Durasi lamanya menuntut elmu/budaya panengen paling cepat 1 (satu) tahun atau tergantung ilmu yang dikehendaki oleh murid. Biasanya menurunkan elmu/budaya panengen ini pada bulan Mulud (Rabi al-Awwal), diakhiri setiap bulan Mulud (Rabi al-Awwal) juga. Setiap bulan minimal ada pertemuan (ngaderes) mengenai jampijampi/petuah atau filsafat kehidupan yang disampaikan sesepuh, yang harus dihapal dan dimaknai sehingga hafal dan paham 
betul persis seperti apa yang disampaikan oleh guru/sesepuh. Setiap murid didampingi oleh murid lainnya yang telah jadi murid lebih dahulu (senior). Guru tidak membatasi bahwa menghafal dan memahami dilaksanakan sebulan sekali di rumah guru. Para murid itu boleh, sebelum bertemu sebulan sekali, mengadakan pertemuan di rumah seniornya yang telah ditentukan oleh guru. Uniknya, semua yang diajarkan gurunya tidak boleh (pamali) atau tabu ditulis. Semuanya harus hafal dan paham di luar kepala. Selama para murid belum hafal dan paham, maka dianggap belum lulus. Kegiatan ngaderes elmu/budaya panengen dilaksanakan malam hari ketika suasana telah sepi dan sunyi (jempling), orangorang lain sudah tidur.

Sepanjang satu tahun sering diadakan ritual berdasarkan penemuan sang guru atas ajaran yang diberikan terhadap muridnya. Bila dipandang perlu pada saat tertentu, karena ada murid yang hatam/lulus, biasanya mengadakan ritual yang berlangsung dan dipimpin oleh gurunya. Tetapi puncaknya ritual tetap pada bulan yang sama ketika diterima menjadi murid yaitu bulan Mulud ( Rabi al-Awwal).

Ritual ini sudah lama berlangsung dan tidak ada seorangpun yang dapat memberikan penjelasan, kapan mulai orang desa Cikalong melaksanakan ritual ini, yang jelas hal ini berlangsung turun menurun dari karuhun hingga saat ini.

Dari hasil pengamatan penulis, bahwa tidak dapat dimungkiri telah terjadi beberapa pergeseran dan perubahan di masyarakat baik secara kewilayahan maupun secara sosial. Secara kewilayahan bahwa budaya panengen ini telah mengalami penurunan pengikutnya terutama di dusun Cimanggu, dan Cikalong, sedangkan di dusun Citembong masih kuat menganut, menaati ajaran-ajaran budaya panengen. Namun dimana-mana tengah terjadi perubahan-perubahan.
Menurut Soerjono Soekanto (2000), dalam bukunya berjudul Sosiologi Suatu Pengantar, menyebutkan bahwa untuk mengadakan perubahan perlu diperhatikan dinamika kelompok sosial sebab melalui dinamika kelompok sosial itu dapat diketahui kehidupan kelompok-kelompok sosial itu sendiri. Menurut Floyd D. Ruch dalam W. A. Gerungan (1978), dalam bukunya berjudul Psychology And Life, memberi penjelasan bahwa dinamika kelompok (group dinamics) adalah analisis dari pada relasi-relasi kelompok sosial, yang berdasarkan prinsip bahwa tingkah laku dalam kelompok itu adalah hasil dari pada interaksi yang dinamika antara individu-individu dalam situasi sosial. Dari pengertian ini terdapat dua hal penting yaitu penyesuaian dan penerusan. Proses penyesuaian ini tidak selalu dapat berjalan dengan lancar, karena tetap membuka kemungkinan-kemungkinan goncangan sosial dan psikologis. Hal ini dapat memakan waktu yang lama; dan juga meminta segala kesabaran dan kebijaksanaan.

Dalam proses penyesuaian ini keadaan masyarakat umumnya rawan, karena nilainilai lama mulai ditinggalkan, sedang nilai baru belum melembaga secara internal. Di sinilah letaknya betapa pentingnya penghayatan dan pengamalan Pancasila membatasi diri pada hal yang pokok, pada intinya yang tidak berubah. Hasil penelitian di Desa Cikalong, menunjukan bahwa dalam budaya panengen tersebut terdapat pimpinan informal (sesepuh). Bila diteliti secara mendetil ternyata banyak akibat dari pimpinan informal yang tumbuh di masyarakat yang nantinya dapat menimbulkan stratifikasi tertentu. Pimpinan informal (sesepuh) tersebut mempunyai kedudukan istimewa di masyarakat, mereka (sesepuh) dianggap orang yang lebih mampu "weruh sadurung winarah" (tahu akan apa yang akan terjadi) dalam arti berilmu untuk mengetahui rahasia-rahasia kehidupan. Jika di antara para 
penganut budaya panengen di masyarakat Desa Cikalong hendak mengadakan perhelatan pernikahan, membuat rumah dan sebagainya, kedudukan pimpinan informal (sesepuh) menjadi istimewa sebab dialah yang menentukan waktu untuk hari perayaan atau pelaksanaan tersebut. Mereka sangat berpengaruh dalam interaksi antar sesama warganya. Tidak jarang petuah-petuah pimpinan informal (sesepuh) merupakan hal yang harus dijaga dan terpelihara serta ditaati dalam hubungannya dengan kehidupan bermasyarakat. Dengan demikian dapat kita pahami bahwa di dalam masyarakat terdapat dualisme komando, perintah, atau pengarahan yang ditaati oleh masyarakat yakni ketaatan kepada sesepuh sebagai pimpinan informal dan ketaatan kepada kepala desa sebagai pimpinan formal.

Guru budaya panengen adalah sesepuh yang merupakan tokoh sentral dalam kehidupan masyarakat desa Cikalong, sesepuh mempunyai dampak dalam tata nilai di desa Cikalong, kehidupan, lingkungan dan spiritual. Dalam pengaturan tata nilai telah terwujud hal-hal yang positif nilai-nilai: komitmen, loyalitas ajaran hubungan guru dan murid, individual dan sosial. Integritas, pamali memiliki barang bukan haknya, tidak menyukai pertengkaran, tidak mencuri, tidak maksiat (persyaratan menjadi murid). Pola hidup sederhana dan tidak serakah, basajan (hidup sederhana dan tidak sombong), gotong-royong, cerminan hidup kemasyarakatan untuk saling membantu, dan tolong menolong. Demikian beberapa hal yang merupakan peran dan fungsi budaya panengen dan peran sentral guru sebagai sesepuh yang dapat mengarahkan, membimbing dan memutuskan bagi para penganutnya sebagaimana seorang pemimpin dalam suatu organisasi.

Dalam kaitan dengan implementasi pembangunan, dari tradisi tersebut sebenarnya dapat dijadikan "momen wisata" yang dikemas dalam kalender desa wisata dan budaya. Misalnya ritual tahunan nga- buku taun dapat diagendakan sebagai kalender tahunan destinasi wisata kabupaten Pangandaran. Begitu juga dengan ritual yang lainnya yang akan memperkaya varian budaya lokal yang sekaligus berkontribusi terhadap pembangunan.

Dengan demikian, pembangunan masyarakat Desa Cikalong menuju desa wisata dan budaya dalam kerangka modernitas dapat terwujud sepanjang merespon keseimbangan dualisme kepemimpinan informal (sesepuh) dan kepemimpinan formal (kepala desa).

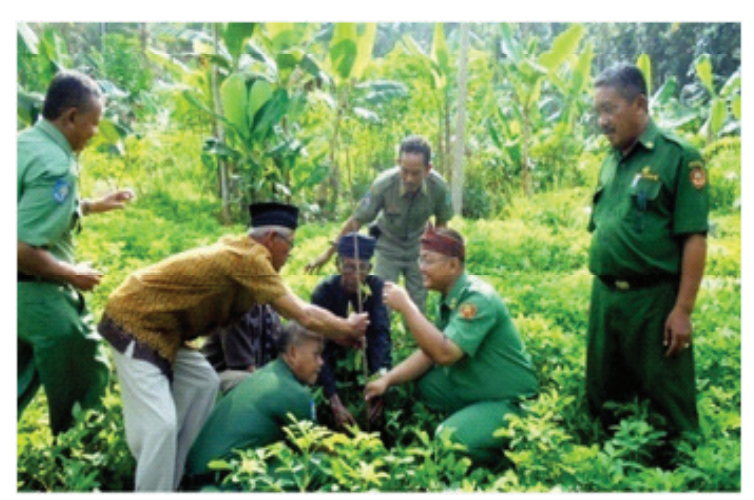

Gambar 12. Penanaman seribu pohon bersama sesepuh dan kepala desa disaksikan Camat. Sumber: Aman Suherman 2015.

\section{SIMPULAN}

Di zaman modern seperti sekarang ini, masyarakat Desa Cikalong masih menaati dan mengamalkan budaya, tradisi ritual ajaran leluhurnya.

Budaya panengen hingga saat ini masih terpelihara (dimumule) oleh masyarakat desa Cikalong, karena memelihara tradisi karuhun (leluhur) sudah tertanam di hati warga yang merupakan keharusan.

Di dalam budaya panengen terdapat nilai-nilai luhur tata kehidupan yang turut mengatur hidup dan kehidupan (hirup jeung huripna). Dalam kehidupan seharihari budaya panengen terwujud pada interelasi antar warga di dalam masyarakat, seperti gotong-royong, saling tolong-menolong, hidup sederhana, tidak sombong dan tidak serakah (basajan), menyadari ke- 
beradaan sang Maha Pencipta (spiritualis), dan sifat-sifat positif lainnya yang tumbuh dan berkembang dalam budaya panengen.

Karakter seperti jujur, etis, saling menghargai, toleran, tidak serakah, rukun dan damai serta menanamkan spiritualitas, merupakan nilai-nilai luhur internalisasi budaya panengen, yang sangat diperlukan negara Indonesia yang saat ini di tengahtengah maraknya dekadensi moral dan derasnya era globalisasi.

Pembentukan karakter dimaksud tidak terlepas dari peran sentral dan fungsi guru/sesepuh sebagai pimpinan informal (informal leader) di desa Cikalong, sehingga aman, tentram dan berbudi pekerti yang luhur selalu terjaga.

Dengan demikian, keberadaan sesepuh dalam kehidupan bermasyarakat sangat berpengaruh dan dibutuhkan untuk pemerintahan desa Cikalong.

\section{Daftar Pustaka}

Fowler H.W and Fowler F.G.

1952 The Concise Oxford Dictionary of Current English. London. Oxford At The Clarendon Press.

Gerungan, WA.

1978 Psychologi Sosial. Badung: Eresco.
Gie, The Liang et.al

1982 Ensiklopedi Administrasi. Jakarta: Gunung Agung.

Harsoyo.

1977 Pengantar Antropologi. Bandung: Bina Cipta.

Masri Singarimbun.

1989 Metode Penelitian Survai. Jakarta: LP3 ES. Djakarta: Penerbit Widjaja.

Munandar Sulaeman.

2012 Ilmu Budaya Dasar. Bandung: Refika Aditama.

Moh. Sjafa'at,

1961 Mengapa Anda Beragama Islam. Jakarta: Penerbit Widjaja.

Soerjono Soekanto.

2000 Sosiologi Suatu Pengantar. Jakarta: Raja Grafindo.

Tuti Rachmawati.

2016 Metode Pengumpulan Data dalam Penelitian Kualitatif. Bandung: UNPAR Press.

Sumber Lain:

Supandi, Upang. 2015.

Laporan Kepala Desa Cikalong. 